\title{
Relationship between feeding and vertical distribution of bivalve larvae in stratified and mixed waters*
}

\author{
Danièle Raby ${ }^{1}$, Yvan Lagadeuc ${ }^{2}$, Julian J. Dodson ${ }^{1, * *}$, Marc Mingelbier ${ }^{1}$ \\ ${ }^{1}$ Département de Biologie, Université Laval, Ste Foy, Québec, Canada G1K 7P4 \\ ${ }^{2}$ Station Marine, Université de Lille, BP 80, F-62930 Wimereux, France
}

\begin{abstract}
We documented the vertical distribution, species composition, size and feeding of bivalve veligers in vertically stratified and well-mixed waters of the Baie des Chaleurs, Québec, Canada. Larvae aggregated at certain depths in both types of water column. When a pycnocline was present, the mean depth of veligers was generally below it. Veligers' vertical distribution was not related to that of water chlorophyll a except at night in stratified conditions. In stratified waters, gut chlorophyll a content of larvae was associated with water chlorophyll a concentration. In mixed waters, larval gut content was similar at all depths. Turbulence seemed to be associated with increased gut content. Diel vertical migration was observed for three of the four $24 \mathrm{~h}$ sampling periods and was apparently associated with an increase in feeding activity.
\end{abstract}

KEY WORDS: Bivalve larvae Feeding - Gut content - Veliger Vertical distribution - Stratified and mixed waters

\section{INTRODUCTION}

Bivalves produce large numbers of pelagic planktotrophic larvae which spend several weeks in the water column before settling. Food availability is one of the main factors that can affect their development and subsequent juvenile recruitment. Even if bivalve larvae are capable of surviving several days without food (Bayne 1965), they still need to feed sufficiently in order to accumulate lipid energy stores necessary for metamorphosis. In the study of Gallager et al. (1986), high larval survival was always associated with high lipid content.

Most investigations on bivalve larvae feeding have been conducted in laboratory conditions for hatchery production purposes. Essential information has been obtained concerning the food value of different species of algae and their optimal concentrations. The main

- Contribution to the program of OPEN (Ocean Production Enhancement Network, National Center of Excellence, Natural Sciences and Engineering Research Council, Canada) and GIROQ (Groupe Interuniversitaire de Recherches Océanographiques du Québecj

-Addressee for correspondence criterion measured to evaluate the success of different diets has been the growth rate of larvae. This generally increases with algal concentration, depending on the nutritive quality of the algal cells (Bayne 1965. Pechenick et al. 1990).

In the field, when the water column is stratified, food concentrations usually vary with depth. Thus, we might expect larvae to be better fed if they graze in the layer of maximum food concentration. As bivalve larvae are capable of adjusting their vertical position in the water column by swimming (Bayne 1976), we might also expect them to aggregate in the layer of maximum food. On the other hand, when the water column is well mixed and food evenly distributed, we would expect larval nutritional status to be equivalent at all depths and larvae to be evenly distributed throughout the water column.

Besides food concentration, small-scale turbulence in the water column is another factor that might modify veliger feeding. For the same food concentration, rate of contact between larvae and food cells is accelerated by water turbulence. According to Rothschild \& Osborn (1988), this effect is greatest for the slowestmoving organisms, such as lamellibranch veligers. In the advent of water column mixing, we may thus expect the feeding rate of veligers to increase. 
Another aspect of the feeding ecology of bivalve larvae concerns diel feeding rhythms. Diel feeding, which is often associated with diel vertical migration, is not well documented for veligers. Vertical migration was observed by Scrope-Howe \& Jones (1986) for the whole community of lamellibranch veligers and by Tremblay \& Sinclair (1990b) for scallop larvae. Harding et al. (1986) detected vertical migration by lamellibranch veligers in a shallow marine embayment. They observed that the median population depth was below $20 \mathrm{~m}$ during the day and rose abruptly at dusk to reach $7.5 \mathrm{~m}$ by $20: 00 \mathrm{~h}$. They also followed the feeding of larvae during this migration by visually assessing the presence or absence of food in their digestive tracts. Fewer larvae had full guts during the dusk ascent, although bivalve larvae had equally full guts during the rest of the day.

In the present study, we investigated the feeding dynamics of bivalve larvae in their natural habitat using chlorophyll $a$ (chl a) in the gut content as an index of feeding. We consider that $\mathrm{chl} a_{i}$ which is mainly present in the stomachs, should be a better marker of recently ingested food than total pigment content (chl a + phaeopigments + other body pigments), as often used for in situ feeding investigations of copepods (Mackas \& Bohrer 1976. Head 1992). Chl a gut content allows us to perceive the level of recent feeding activity, because it is rapidly degraded after ingestion. By contrast, larval total pigment content would not be representative of recent feeding activity, because lipid reserves in the digestive gland are chromophilic (i.e. absorb pigments). Gelder \& Robinson (1980) confirmed that pigments localized in adult mussel digestive gland were phaeopigments. When observed under epifluorescence microscopy, lipid spherules contained in digestive glands of bivalve larvae fluoresce red/orange, as is typical of phaeopigment (pers. obs.). In addition, depending on age and condition, lipid content of bivalve larvae can represent up to $23 \%$ of dry body weight (Gallager et al. 1986).

Pigment extraction has not previously been used to study the feeding of bivalve larvae, but has been employed to assess the nutritional status of adult oysters (Mann 1977). After 24 h of starvation, more than $50 \%$ of the oysters' pigment content was lost. Hawkins et al. (1986) demonstrated the utility of chl a as a diet-specific marker of ingested matter for adult mussels. Even if bivalve larvae can also feed on other food resources such as bacteria (Martin \& Mengus 1979, Prieur 1983) and dissolved amino acids (Manahan \& Crisp
1983), it is generally accepted that phytoplankton is their principal food source.

In order to improve our understanding of bivalve larval feeding ecology, we addressed the following questions: (1) Is the level of feeding activity dependent on food concentration? (2) Do bivalve larvae aggregate in the maximum food layer in stratified waters and disperse evenly in well-mixed waters? (3) Do larvae exhibit either diel vertical migration, or diel feeding rhythm?

To answer these questions, bivalve larvae were sampled along the north shore of Baie des Chaleurs, eastern Canada (Fig. 1) at 2 stations $110 \mathrm{~km}$ apart, one with a stratified water column and one which was homogeneous with depth. We expected species composition to differ between stations so we monitored species composition and size of larvae. Veligers of different sizes and/or species might have different gut chl a contents, independent of variations due to food concentration or depth distribution.

\section{MATERIAL AND METHODS}

Sampling procedure. In order to investigate the differences in vertical distribution and feeding of bivalve larvae in stratified and well-mixed water masses, 2 stations were chosen according to their hydrodynamical structure. The stations were chosen after 2 sampling series of 60 stations, in the Baie des Chaleurs, at the beginning of September 1991. The stratified station (20 m depth) was close to Caplan, located well inside the Bay, and was sampled from 10 to 12 September. Sampling of a vertically mixed water column (20 $\mathrm{m}$ depth) was carried out $8 \mathrm{~d}$ later at Grande-

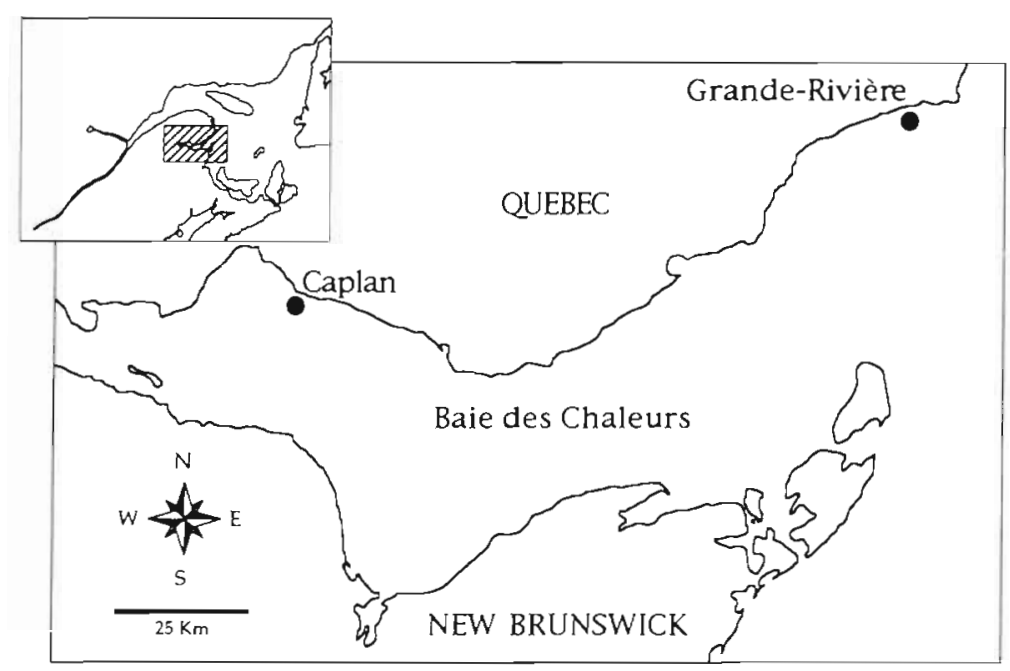

Fig. 1. Locations of the 2 anchor stations along the north shore of Baie des Chaleurs, eastern Canada 
Rivière, close to the entrance of the Bay (Fig. 1). At each anchor station, sampling was carried out every $2 \frac{1}{4} \mathrm{~h}$ over a period of $52 \mathrm{~h}$, for a total of 23 profiles. Measurements of physical parameters and in situ fluorescence were taken every hour from the surface to $20 \mathrm{~m}$ depth with a CTD Seabird SBE25 and a Sea Tech fluorometer in order to detect any changes in the water column structure and in the in situ fluorescence.

Measurements of chlorophyll a. Seawater samples were collected at $5 \mathrm{~m}$ intervals from 0 to $20 \mathrm{~m}$ for measurements of chl a concentration. After prefiltration on a $200 \mu \mathrm{m}$ nylon filter, the samples were fractionated into 3 size classes using sequential filtration on 20 and $5 \mu \mathrm{m}$ nylon filters (Nytex) and on $0.7 \mu \mathrm{m}$ fiberglass filters (Whatman GF/F). After 24 h extraction in $90 \%$ acetone, the chl a concentrations were determined for each fraction using the fluorometric technique of Holm-Hansen et al. (1965). Those profiles were repeated every $2 \mathrm{~h}$.

Bivalve larvae ingested particles no larger than $25 \mu \mathrm{m}$ in diameter, as observed under the epifluorescence microscope. Chl $a<20 \mu \mathrm{m}$ comprised most of the total chl a. Mean percentages of chl a $<20 \mu \mathrm{m}$ for all depths were 91 to $97 \%$ at Caplan and 84 to $89 \%$ at Grande-Rivière. Thus, total extracted chl a was considered to be available as food for bivalve larvae.

Vertical distribution of veligers. Larvae were sampled every 2 h using a high volume pump (Flygt, model C/D-3085) equipped with a digital flowmeter. To document their concentration and follow their vertical movement, water was pumped for $5 \mathrm{~min}$, at $2 \mathrm{~m}$ intervals, from 2 to $20 \mathrm{~m}$ depth. Samples for counting were filtered through a $64 \mu \mathrm{m}$ mesh net and preserved in $4 \%$ seawater formalin buffered with sodium borate. Counts of bivalve larvae were done by volumetric subsampling. At least 100 individuals were counted per sample. The profiles took an average of $60 \mathrm{~min}$ to complete, after which more intense sampling $(10 \mathrm{~min}$ pumping per depth) was done at 2, 4, 8 and $14 \mathrm{~m}$ to obtain sufficient larvae for further analysis. These veligers were immediately separated from the other lighter plankton components by centrifugation with Ludox, a colloidal silica (Tremblay \& Sinclair 1987), rinsed twice with filtered seawater (GF/F $0.7 \mu \mathrm{m}$ filter), separated into 2 subsamples, and deep-frozen in liquid nitrogen. The first subsample was used to identify and measure larvae in order to detect changes in species composition and size structure of the veliger community. The second subsample was used for gut pigment extraction. Because of the number of depths sampled, there was a lapse of $1 \mathrm{~h}$ between the start of sampling of larvae for counts (10 depths) and the start of sampling for larvae used for chl a extraction, measurements and taxonomic identification ( 4 depths). Lengths (antero-posterior axis) of 50 larvae per sample were measured to the nearest $6 \mu \mathrm{m}$ with a microscope fitted with a calibrated ocular micrometer. Identification to genus or species was based on the shell morphology (Chanley \& Andrews 1971, Le Pennec 1980, Lutz et al. 1982). Fifteen samples were taken from different times and depths to confirm the identifications by observation of the hinge structure of the separated valves, using a scanning electron microscope. Because scallop valves were difficult to open, an immunofluorescent probe was used to confirm their identification (Demers et al. 1993).

Gut pigment extraction. After quickly thawing a sample, approximately 200 larvae were picked out under cold light using a binocular microscope. Larvae were rapidly homogenized in $6 \mathrm{ml}$ of $90 \%$ aqueous acetone with a sonicator and left for $1 \mathrm{~h}$ in the dark, on ice. After centrifugation, fluorescence of the supernatant was measured on a Turner 112 fluorometer before and after acidification with 10\% hydrochloric acid. Each sample was treated in triplicate. The weight of chl a extracted from the gut content was calculated using the equations of Strickland \& Parsons (1972) and used as a feeding index. Chl a represented approximately $40 \%$ of total pigments which is high compared to other studies (Head 1992). This suggests that chl $a$ degradation was minimal before extraction was done.

Data analysis. Depth of the pycnocline $(P)$ was calculated as follows: $P$ was taken as the center of the $6 \mathrm{~m}$ interval where the change in sigma- $t$ was maximum. The index of density stratification $(S)$ was calculated as

$$
S=\Delta \text { sigma }-t / 20 \mathrm{~m}
$$

where $\Delta$ sigma- $t$ is the difference in sigma- $t$ over $20 \mathrm{~m}$.

The mean depth of veligers for each profile was calculated as in Fortier \& Leggett (1982):

$$
\text { center of mass }(\mathrm{ZCM})=\sum_{t=1}^{n} p_{i} z_{t}
$$

where $p_{i}=$ proportion of the total number of larvae caught within the $i$ th depth interval; and $z_{1}=$ middepth of the $i$ th interval.

Variations of specific composition of veligers between different depths and times were investigated using multidimensional variance analyses (MANOVA). For the other grouped data comparisons (day/night, between depths and profiles), analyses of variance were used with Scheffe's ' $S$ ' post-hoc test when the basic assumptions were met. Otherwise, the Welch ANOVA non-parametric test was used.

The concentration of chl a in the water column was sampled at only 5 discrete depths in each profile, providing little precision compared to the continuous in situ fluorescence recordings. Therefore, estimated chl a concentrations were used to better evaluate the depths of 


\section{Caplan}

(a) Larvae $\mathrm{m}^{-3}$

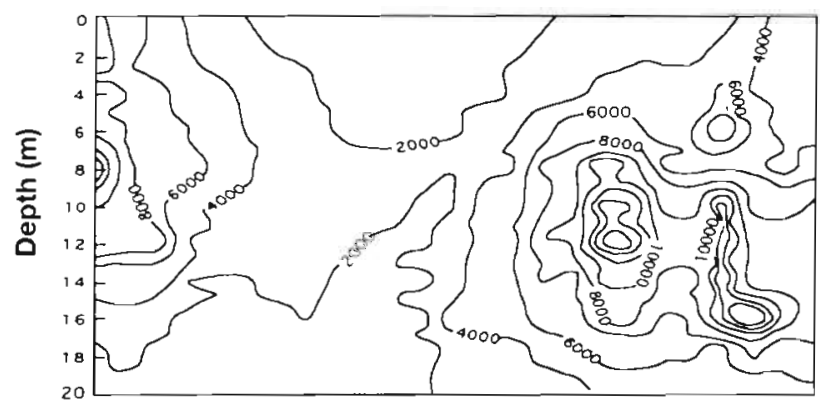

(b) Temperature $\left({ }^{\circ} \mathrm{C}\right)$

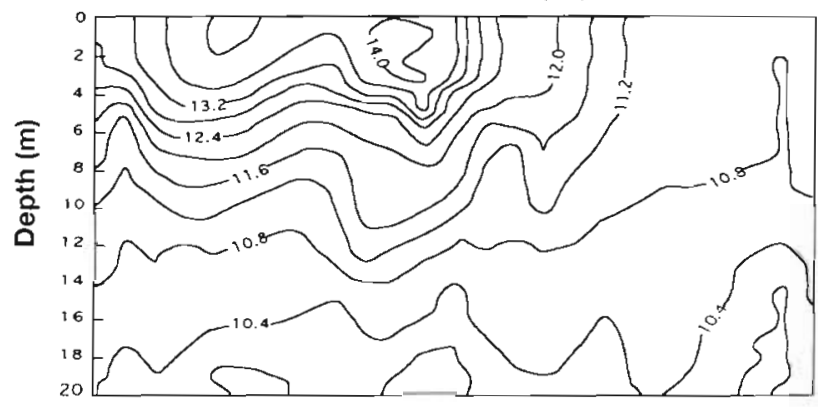

(c) Salinity (ppm)

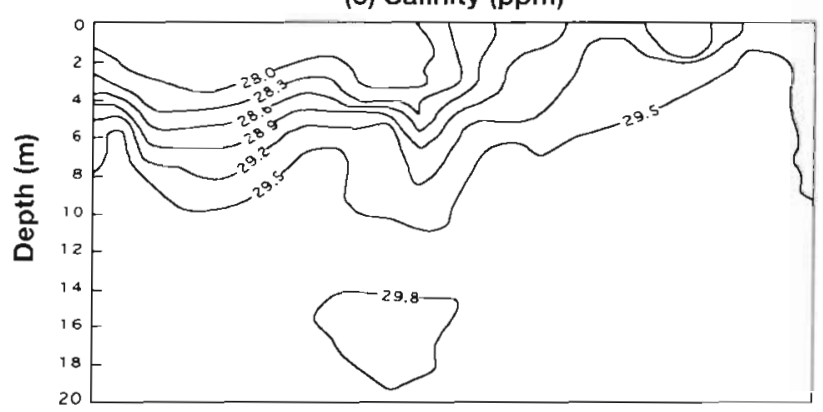

(d) In situ fluorescence

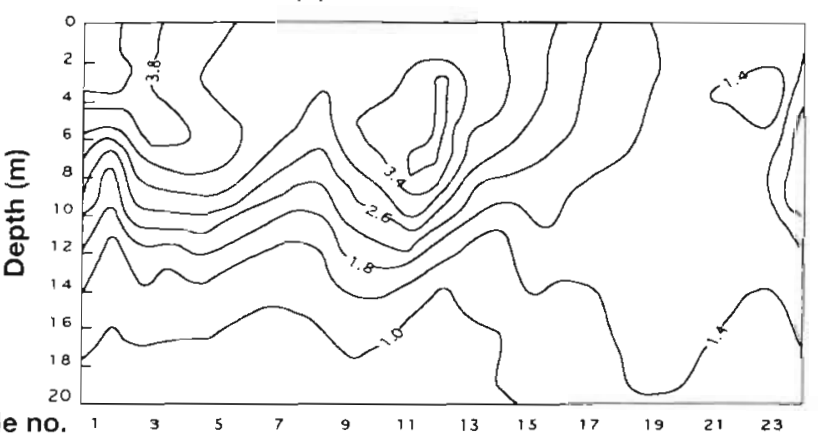

Tide

Day/Night

Fig. 2. Time-depth contour diagram of (a) bivalve larval concentration, (b) temperature, (c) salinity and (d) in situ fluorescence for Caplan anchor station 4 and indıcate high tide and low tide, respectively

\section{Grande-Rivière}

(a) Larvae $\mathrm{m}^{-3}$

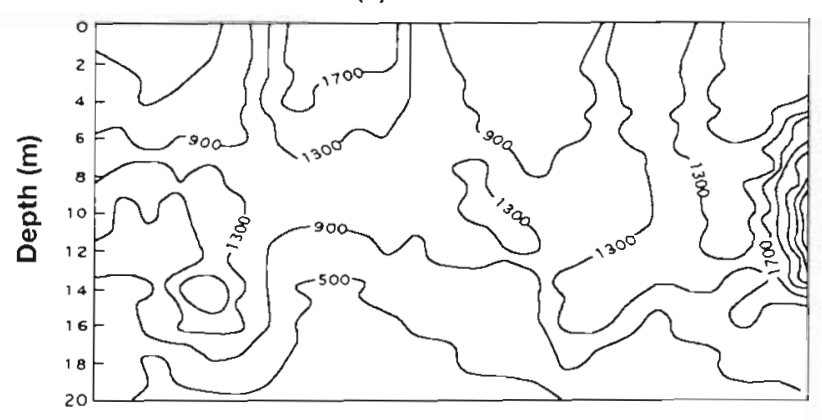

(b) Temperature $\left({ }^{\circ} \mathrm{C}\right)$

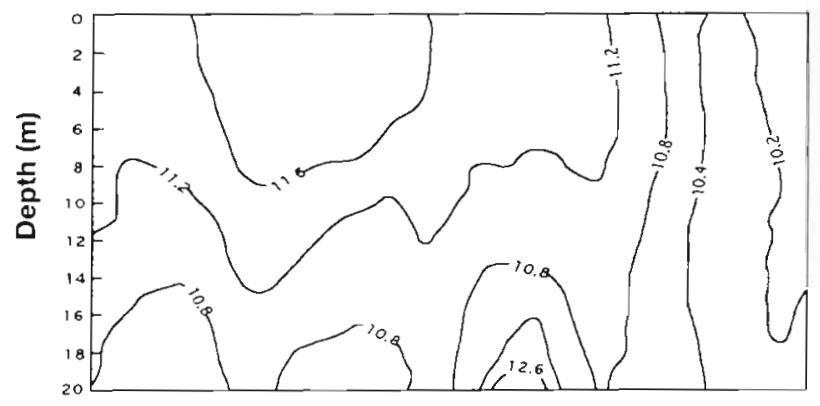

(c) Salinity (ppm)

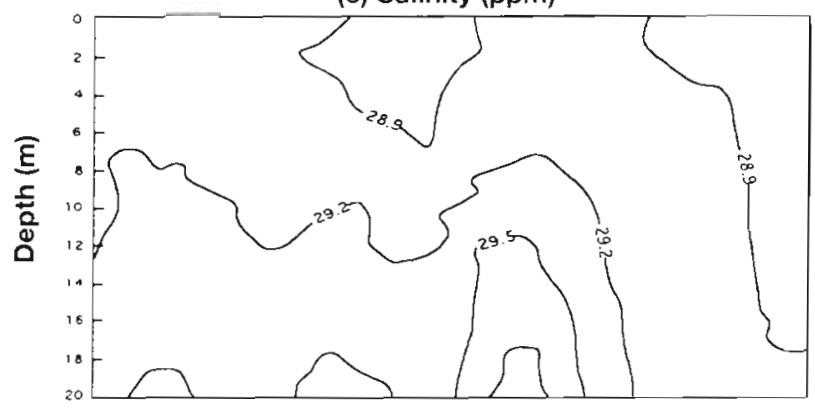

(d) In situ fluorescence

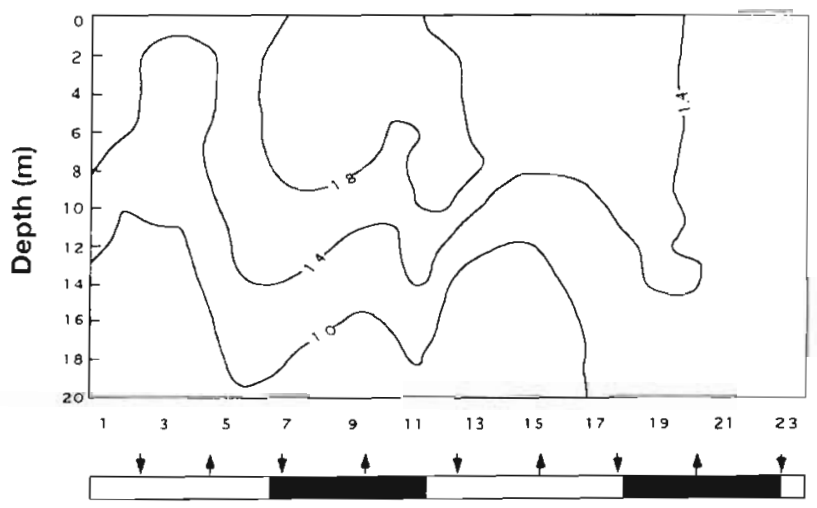

Fig. 3. Time-depth contour diagram of (a) bivalve larval concentration, (b) temperature, (c) salinity and (d) in situ fluorescence for Grande-Riviere anchor station. and indicate high tide and low tide, respectively 
maximum chl a concentrations for the stratified profiles and to compare the distributions of both larvae and their potential food resource. For the 23 profiles taken in the stratified water column at Caplan, chl a was strongly correlated with in situ fluorescence (Spearman's Rho $=0.89$ ). Thus, in situ chl a was estimated as follows:

$$
\text { chl } a\left(\mu \mathrm{gl}^{-1}\right)=0.295-7.69^{-2 F}+0.118 F^{2}
$$

where $F$ is the in situ fluorescence. Estimated chl a was also used to determine the mean depth of potential food resources for Caplan stratified profiles.

The correlation between extracted water chl $a$ and in situ fluorescence was weaker at the Grande-Rivière station (Spearman's Rho $=0.628$ ). As a result, chl a was not estimated from in situ fluorescence at this station.

\section{RESULTS}

\section{Bivalve larvae concentration and water column structure}

Bivalve larvae were 5 times more abundant at Caplan than at Grande-Rivière. The total number of larvae in the water column varied between profiles, but these variations were not related with either tides or light (Figs. 2a \& 3a)

During the first 14 profiles at Caplan, the water column was stratified $(0.065<S<0.125$, Fig. 2 b, $c, d)$, but a strong wind that started at the 12th profile caused mixing of the water column. Thus, during profiles 15 to 23 , the water column was homogeneous $(0.006<S<$ 0.055 ). At Grande-Rivière, the water column was always homogeneous with stratification index values ranging between 0.006 and 0.055 (Fig. 3b, c, d).

\section{Food availability}

At Caplan, chl a maxima concentrations per profile ranged from 1.4 and $5.3 \mathrm{\mu g} \mathrm{l}^{-1}$ for stratified profiles and dropped $40 \%$ to between 0.45 and $1.0 \mu \mathrm{g} \mathrm{l}^{-1}$ after water column homogenisation. Grande-Rivière chl a maxima concentrations were between 0.32 and $1.78 \mu \mathrm{g} \mathrm{l}^{-1}$. A slight gradient in chl a concentration was occasionally present at this station despite the fact that the water column was homogeneous. At such times, it was most concentrated at 0 and $5 \mathrm{~m}$. There were no differences between day and night chl a concentrations for either station (Welch ANOVA, p > 0.05). Mean depth of the maximum concentration of food was calculated for stratified profiles only because the mean depth has no significance when calculated for a homogeneous water column. The mean depth of maximum chl a concentration ranged from 6.7 to $8.3 \mathrm{~m}$ (Fig. 4a).

\section{(a) Caplan}

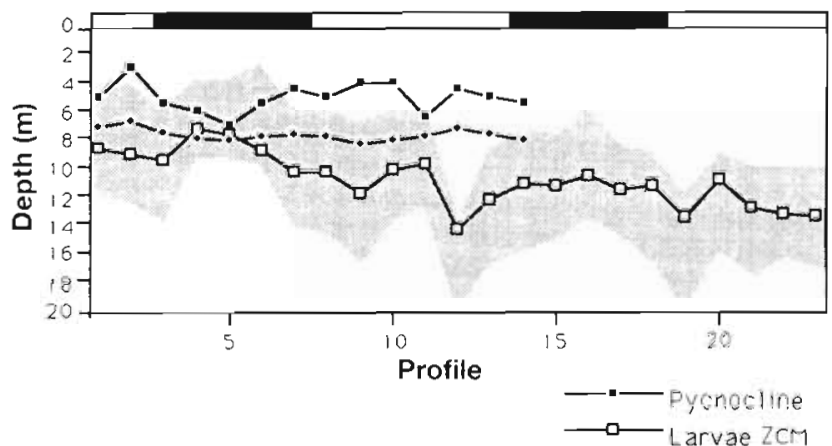

(b) Grande-Rivière

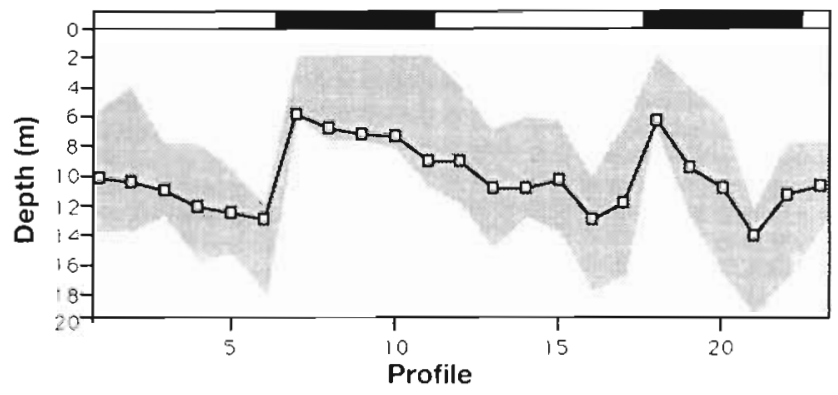

Fig. 4. Mean depths (center of mass, ZCM) of bivalve larvae for all profiles sampled at Caplan and Grande-Rivière. The extent of larval aggregation is represented by the shaded area which represents the smallest depth interval in which $70 \%$ of the larvae are found for each profile. Water chl a mean depths and pycnocilne depths were calculated for stratified profiles only. Open bars = daylight hours, dark bars = night

\section{Species composition and larvae size}

At Caplan, blue mussels Mytilus edulis were dominant followed by soft-shelled clams Mya arenaria, whereas the reverse situation was observed at GrandeRivière (Table 1, Fig. 5). In addition, MANOVA detected a significant difference in species composition during the last profiles sampled at Caplan, when the proportion of mussels declined dramatically and that of clams increased. To avoid any bias due to taxonomic differences in feeding, profiles 22 and 23 were not included in analyses concerning feeding. MANOVA also detected a difference in species composition between profiles for Grande-Rivière samples, but it was not significant when tested with Scheffe's ' $S$ ', one species at a time $(p>0.05)$. Thus, no profiles were deleted from the analyses concerning feeding. At both stations, the species composition was the same between depths and did not fluctuate with day and night (Table 2).

Larval mean length was $276 \pm 34 \mu \mathrm{m}$ at Caplan and $296 \pm 51 \mu \mathrm{m}$ at Grande-Rivière. Lengths of the larvae were smaller for profiles 14 and 18 at Caplan (Scheffe, $p<0.05$ ). This difference represented only 
Table 1. Bivalve larvae species composition at Caplan and Grande-Rivière anchor stations. Species proportion changed at the end of Caplan sampling mission for profiles 22 and 23 A: Caplan profiles 1 to 22; B: Caplan profiles 22 and 23; C: Grande-Rivière station

\begin{tabular}{|lrcr|}
\hline Species & \multicolumn{3}{c}{ Mean percentage } \\
& A & B & C \\
\hline Mytilus edulis & 75 & 47 & 14 \\
Mya arenaria & 5 & 22 & 68 \\
Pectinidae & 3 & 5 & 5 \\
Anomia sp. & 1 & 1 & 1 \\
Other species & 16 & 25 & 12 \\
\hline
\end{tabular}

$5 \%$ of the mean length and did not cause any effect on the feeding index. Veligers from Grande-Rivière were significantly smaller at the end of the sampling, for profiles 18, 19, 20, 22 and 23 (Scheffe, $p<0.001$, Fig. 6). The average decrease in length was $29 \mu \mathrm{m}$ for these profiles, and the corresponding gut chl a content was significantly lower (Scheffe, $p<0.05$ ). These profiles were not included in analyses of feeding activity. For both stations, length variations between depths $(2,4,8,14 \mathrm{~m})$ and between pooled data for day and night were never higher than $11 \mu \mathrm{m}$, which represents $5 \%$ of the mean length. These variations had no effect on the gut chl $a$ content of veligers.
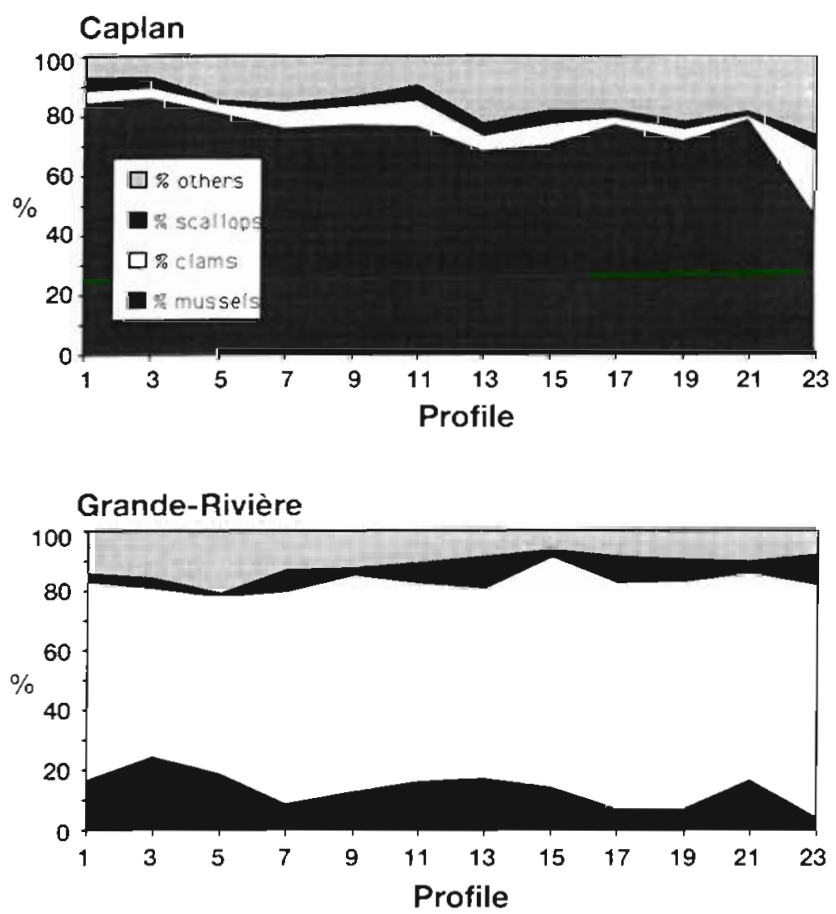

Fig. 5. Species composition of bivalve larvae for all profiles sampled at the 2 anchor stations

\section{Vertical distribution of veligers}

In both stratified and well-mixed water columns, the larvae were aggregated at certain depths which fluctuated between 6 and $14 \mathrm{~m}$ (Fig. 4a, b). During the 14 stratified profiles sampled at Caplan, the depth of the pycnocline varied between 3 and $7 \mathrm{~m}$ (Fig. 4a). Average depths of aggregation of larvae were from 3 to $10 \mathrm{~m}$ below the pycnocline at all times except during 2 profiles at the beginning of the first night, when the 2 depths almost coincided.

The turbulence induced by the wind during the second day at the Caplan anchor station affected the vertical distribution of veligers. Their mean depth was $2 \mathrm{~m}$ deeper after mixing (Welch ANOVA, $\mathrm{p}<0.01$ ), but larvae remained as aggregated as in stratified waters (Fig. 4a).

At both stations, larvae moved towards the surface at night. The average depths at night were significantly shallower than those recorded during the day for 3 of the 4 days sampled (Table 3 , Fig. 7).

\section{Vertical distributions of veligers and in situ chlorophyll a}

Stratified waters. The vertical distribution of larvae (larval concentration at 10 depths $\times 5$ night profiles) was positively correlated with the estimated water chl $a$ (for the same depths and times), at night in the stratified water column (Spearman's Rho $=0.69$, $\mathrm{p}<0.0001, \mathrm{n}=50$ ). At the same station, there was no such correlation during the day (Spearman's Rho = $-0.16, p=0.22, n=60$ ). The proportion of larvae collected at a depth of $2 \mathrm{~m}$ was low compared to the high concentration of chl $a$ at this depth.

The mean depth of larvae was deeper than the mean depth of in situ chl a for 11 of the 14 stratified profiles. Both centers of mass coincided during the only stratified/night observations between 21:00 and 2:00 h (Fig. 4a)

Table 2. Statistical significance of species composition variations in relation to time (profiles), depths and daylight for Caplan and Grande-Rivière anchor stations. Multuvariate analysis of variance (MANOVA) was used with Wilkes' Lambda test. 'Significant $p$-values $(p<0.05)$

\begin{tabular}{|lcc}
\hline Effect & \multicolumn{2}{c}{ p-value } \\
& Caplan & Grande-Rivière \\
\hline Time (profiles) & $0.0001^{\circ}$ & $0.0009^{\circ}$ \\
Depth & 0.1164 & 0.3838 \\
Time $\times$ Depth & 0.0801 & 0.6580 \\
Day/night & 0.2144 & 0.4105 \\
& &
\end{tabular}




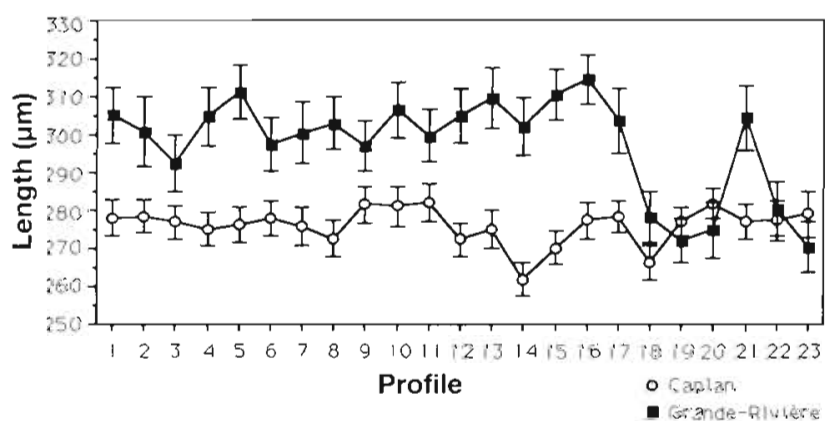

Fig. 6. Bivalve larvae mean length with $95 \%$ confidence intervals (vertical bars) for Caplan and Grande-Rivière stations

Mixed waters. When the water column was well mixed at Caplan, as well as at the vertically mixed station at Grande-Rivière, larvae were still aggregated around a particular depth despite the presence of evenly distributed chl a concentrations (Figs. 2, 3 \& 4).

\section{Relation between feeding index and chlorophyll a distribution}

Stratified waters. In stratified waters where the chl a concentrations varied with depth, feeding differed between depths. Feeding index values were lower at $14 \mathrm{~m}$ than at 2, 4 and $8 \mathrm{~m}$ (Scheffe, $\mathrm{p}<0.05$; Fig. 8). The depths of maximum feeding index values were highly correlated with the depths of maximum water chl a (Spearman's Rho $=0.86, \mathrm{p}=0.004, \mathrm{n}=12$ ). However, water chl a concentration explained only $43 \%$ of the feeding index variability (Spearman's Rho $=0.433$, $\mathrm{p}<0.001, \mathrm{n}=165$ ). Larvae feeding index at $2 \mathrm{~m}$ was usually low compared to the water chl a concentration at this depth, which partly explains this low correlation.

Mixed waters. In Caplan, after the water column was mixed, there were no differences observed between the feeding index measured at different depths (Scheffe, p > 0.05; Fig. 8). Compared to the feeding index values recorded before water column mixing, gut contents from larvae sampled at 2 and $14 \mathrm{~m}$ increased by 16 and $20 \%$ respectively. Feeding was the same at different depths at the Grande-Rivière anchor station (Scheffe, p > 0.05; Fig. 8).

\section{Day/night feeding}

Sampling lasted $2 \mathrm{~d}$ at each station, but feeding data from the second day of sampling at GrandeRivière cannot be used for day/night comparisons due to the change in the larvae population during the last night. For the 3 other days, feeding index values were 14 to $31 \%$ higher during the night than during daylight hours (Table 3, Fig. 9).

Table 3. Mean depths (ZCM) and feeding index of bivalve veligers during daylight hours and night for each 24 h period sampled at Caplan and Grande-Rivière stations. $\Delta$ : difference between day and night values. "Significant differences $(t$-test, $\mathrm{p}<0.05\}$ $\mathrm{ns}$ : non-significant difference $(\mathrm{p}>0.05)$

\begin{tabular}{|c|c|c|c|c|c|c|c|c|}
\hline \multirow[t]{2}{*}{ Station } & & \multicolumn{3}{|c|}{$\mathrm{ZCM}(\mathrm{m})$} & \multicolumn{4}{|c|}{ Feeding index (pg chl a larvae ${ }^{-1}$ ) } \\
\hline & & Daylight hours & Night & $\Delta$ & Daylight hours & Night & $\Delta$ & $\%$ Augmentation \\
\hline Caplan & $\begin{array}{l}\text { Day } 1 \\
\text { Day } 2\end{array}$ & $\begin{array}{l}10.8 \\
12.2\end{array}$ & $\begin{array}{r}8.7 \\
11.2\end{array}$ & $\begin{array}{l}2.1^{\circ} \\
1.0^{\circ}\end{array}$ & $\begin{array}{l}24.8 \\
27.8\end{array}$ & $\begin{array}{l}32.5 \\
30.9\end{array}$ & $\begin{array}{l}7.7^{\circ} \\
3.9^{\circ}\end{array}$ & $\begin{array}{l}31 \\
14\end{array}$ \\
\hline Grande-Rivière & $\begin{array}{l}\text { Day } 1 \\
\text { Day } 2\end{array}$ & $\begin{array}{l}11.8 \\
11.0\end{array}$ & $\begin{array}{r}7.8 \\
10.4\end{array}$ & $\begin{array}{l}4.0^{\circ} \\
0.6 \mathrm{~ns}\end{array}$ & $\begin{array}{c}37.6 \\
-\end{array}$ & $\begin{array}{c}45.7 \\
-\end{array}$ & $\begin{array}{c}8.1^{\circ} \\
-\end{array}$ & $\begin{array}{l}22 \\
-\end{array}$ \\
\hline
\end{tabular}

Fig. 7. Vertical distribution of bivalve larvae during daylight hours (white) and at night (shaded) for each $24 \mathrm{~h}$ period of sampling at both anchor stations. Larval distribution is shown as percentages of total numbers found in the water column for daylight and night profiles. "Indicates that larval mean depth at night is significantly shallower than during daylight hours ( $t$-test, $p<0.05$ )
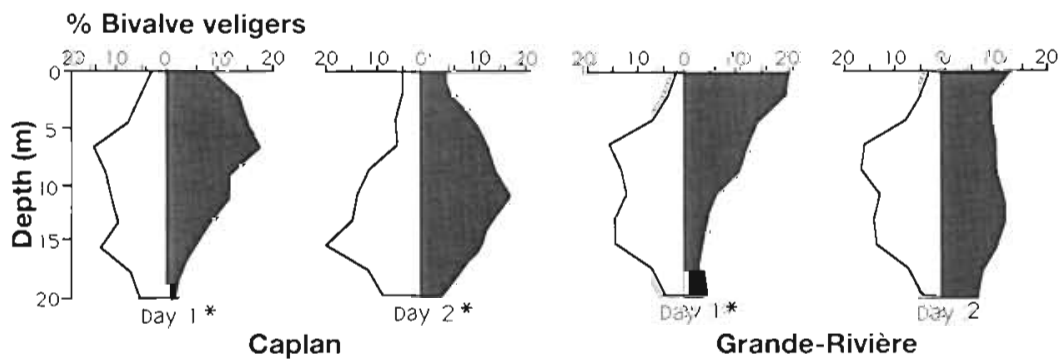


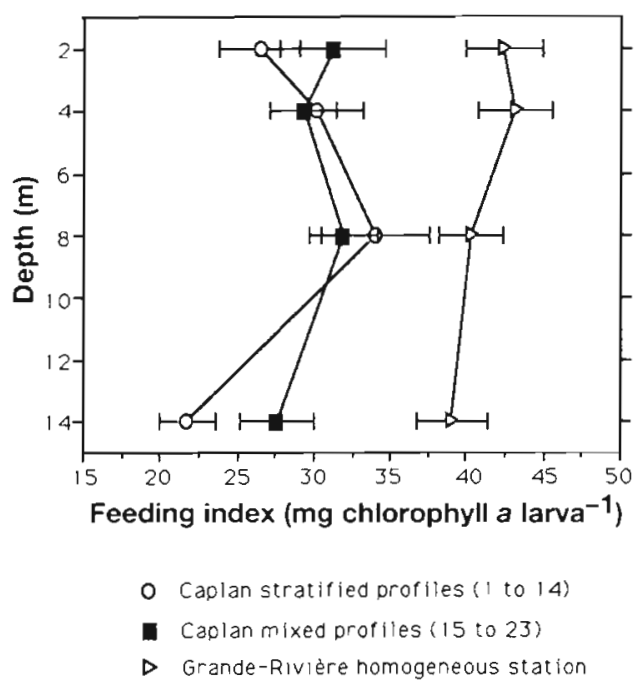

Fig. 8. Feeding index as a function of depth for stratified and mixed water columns. Horizontal bars represent $95 \%$ confidence intervals

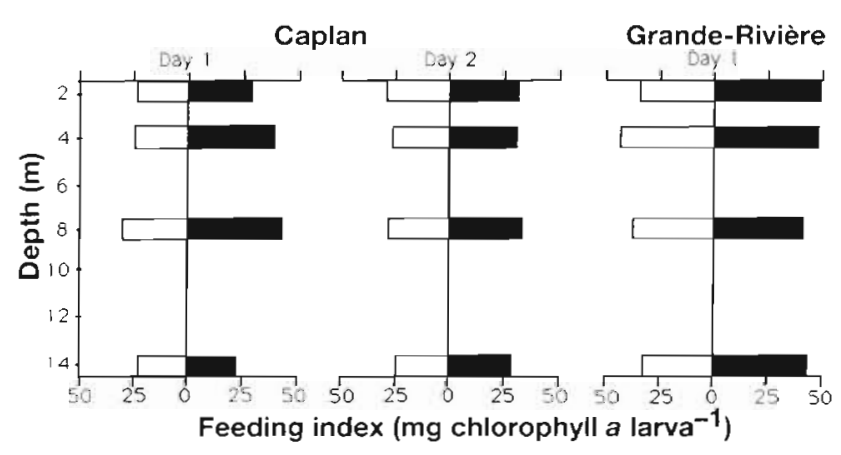

Fig. 9. Feeding index observed during daylight hours (open bars) and at night (black bars) as a function of depth. Feeding indices were significantly higher for the 3 nights (t-test, $\mathrm{p}=0.01$

\section{DISCUSSION}

\section{Species composition and larvae size}

The bivalve veliger community was dominated by blue mussels and soft-shelled clams, which occur in temperate water columns during summer (Sullivan 1948). The increased proportion of clams observed at the end of sampling at Caplan may have been related to water mass advection caused by strong easterly winds which lasted $20 \mathrm{~h}$. Such advection may have transported clams towards Caplan from the mouth of the Bay where clams are more abundant. Scallop larvae were also present in small numbers at both stations, and they were at the maximum size they reach before settlement in that region (240 to $250 \mu \mathrm{m}$; Harvey et al. 1993). The larvae of all species were large, indicating that most of them were close to settlement phase. No straight-hinge veligers were found in the samples from the 2 stations. We thus consider that our study is representative of the later stages of the pelagic life of bivalve larvae.

\section{Veligers' vertical distribution and feeding}

Subsurface aggregation of bivalve veligers was present in both types of water column. This differs from the study of Tremblay \& Sinclair (1990a) who observed that scallop larvae in the Bay of Fundy tended to be more dispersed in mixed waters. However, their study used sampling-interval depths of $10 \mathrm{~m}$. This lack of vertical resolution may have masked a potential aggregation of larvae. Bivalve veligers aggregation was also observed in well-mixed water columns by Mann (1985) on the Southern New England Shelf, and by Harding et al. (1986) in a $30 \mathrm{~m}$ water column characterized by a homogeneous upper layer of $25 \mathrm{~m}$. The fact that bivalve larvae aggregate in homogeneous as well as in stratified water columns indicates that they probably actively regulate their vertical position. Sensitive depth regulatory responses for bivalve veligers have been described by several authors. Different stimuli have been demonstrated to modify the swimming behaviour of veligers, such as light intensity (Bayne 1964, Kaartvedt et al. 1987), salinity discontinuities (Mann et al. 1991) and pressure variations (Bayne 1964. Cragg 1980). Evolution of depth regulation, which leads to larval aggregation, could be the result of selection pressures initiated by the avoidance of demersal predators as well as visual predators in the surface layer and/or the necessity to feed in the upper rich food layer in stratified water masses.

In the Baie des Chaleurs, when the water column was stratified, we observed a small amplitude upward vertical migration during the night. The mean depth of bivalve larvae was associated with the maximum $\mathrm{chl} a$ concentration during the night profiles, and was below it during daytime. This suggests that aggregation is not only related to food availability in stratified waters. Diel vertical migration of zooplankton has often been discussed in terms of upward migration and grazing in the rich food layer at night and downward migration and avoidance of visual predators during the day (Harding et al. 1986, Frost 1988). In the presence of evenly distributed food at the Caplan station after water column mixing and for the first day at the well-mixed GrandeRivière anchor station, bivalve larvae still aggregated at specific depths and migrated vertically, supporting the 
proposition that aggregation and diel vertical migration are not only related to feeding. Predator avoidance may also explain these behaviours in evolutionary terms. Unfortunately, little is known about the pressure from predators on bivalve larvae, although we do know that bivalve larvae can react to changes in light intensity, especially at the later stages. Kaartvedt et al. (1987) found that scallop Pecten maximus larvae adjusted their vertical position in relation to the level of light intensity and Bayne's (1964) experiments with Mytilus edulis larvae showed that pediveligers exhibited negative phototaxis. In the present study, the only night when upward migration was not significant was the second night at Grande-Rivière. This may have been because the smaller larvae present during that night had different behaviour to that of the larger veligers previously observed at the same station. There was however a sharp ascent of larval mean depth at the beginning of the 2 nights in Grande-Rivière ( 7 and $6 \mathrm{~m}$ ). The second night ascent occurred just before the arrival of smaller veligers (profile 18 for enumeration of larvae was done $1 \mathrm{~h}$ before profile 18 for length measurements). Such displacement in $2 \mathrm{~h}$ is consistent with observed vertical velocities of $1 \mathrm{~mm} \mathrm{~s}^{-1}$ (3.6 $\mathrm{m} \mathrm{h}^{-1}$ ) (Mann 1986).

During the three $24 \mathrm{~h}$ periods when vertical migration was observed, feeding increased at night, while no diel changes were observed in the phytoplankton standing stock. For the stratified profiles (Caplan, Day 1), night-time feeding increased at 2, 4 and $8 \mathrm{~m}$ where chl a concentrations were high. Larvae at $14 \mathrm{~m}$, where chl a concentrations were low, had the same feeding index as during the day. Furthermore, during the night, the vertical position of larvae overlapped that of their food. Thus, the vertical upward migration observed in this case was likely related to food distribution and increased feeding. However, a longer sampling period in stratified waters would be necessary to support the generality of this conclusion. In the homogeneous water columns, larvae still migrated upward and increased grazing during the night. The theory of a night ascent to a rich food layer is not applicable here because the food resources gradient was very weak or absent. Thus swimming behaviour may have been a response to a change in light intensity. The night upward vertical migration may have resulted from the fact that veligers are more active at night, in both swimming and feeding, and less active during the day, sinking and feeding less.

In the stratified water mass, feeding was improved when the chl a concentrations in the water were high. Veliger feeding indices were different between depths and were related to chl a concentrations. The fullest larvae were in the same layer as the maximum chl a concentration, whether the larval mean depth was in the same layer or not.
After water column homogenisation at the Caplan anchor station, larval feeding increased at both 2 and $14 \mathrm{~m}$. At depths of 4 and $8 \mathrm{~m}$, gut content values were as high as they were for stratified profiles, despite the fact that chl a concentrations were much lower after homogenisation. As the contact rate between predator and prey depends on both their relative density and velocity (Rothschild \& Osborn 1988), the presence of wind-induced turbulence might have caused this feeding increase by an augmentation of the contact rate between veligers and algae. According to Rothschild \& Osborn (1988), turbulence effect can be important, especially for slow-moving organisms.

Water turbulence may also have had an effect on vertical distribution as well as feeding incidence. At Caplan, when the water column was mixed by wind forces, there may have been an increased frequency of collisions between larvae and other particulate matter inducing veligers to retract their velum, close their valves and thus momentarily sink (Carriker 1986). Although highly speculative, these results suggest the possibility of critical interactions between turbulence, extension or retraction of the velum, feeding activity and depth distribution that merits closer investigation

A method used for the first time to investigate bivalve larvae feeding in the field enabled us to detect short-term fluctuations of feeding in natural conditions. The present study has shown that feeding studies concerning bivalve larvae are feasible in natural systems, despite the fact that variability in larval nutritional status has numerous possible sources. As demonstrated in laboratory experiments, larval feeding is enhanced by high food concentrations such as occur in stratified water columns. Our results are also consistent with the hypothesis that small-scale turbulence may influence feeding and depth distribution. However, controlled investigation in the laboratory will be needed to fully test the hypothesis. This study confirms the presence of a small amplitude diel vertical migration for bivalve veligers during the late pelagic stages. For the first time, it was demonstrated that vertical movement was associated with increased feeding.

Acknowledgements. We thank Michel Boulé for his assistance in the mission's organisation and support in the laboratory. We also thank Bert Klein for his scientific advice, Alain Demers for scallop larvae identification, Caroline Berger and Denis Thivierge for their technical assistance and 2 anonymous referees for their constructive criticism of an earlier draft of this paper. This project was supported by OPEN (National Centers of Excellence, NSERC, Ottawa) and grants from FCAR and GIROQ (Groupe Interuniversitaire de Recherches Océanographiques du Québec). 


\section{LITERATURE CITED}

Bayne, B. L. (1964). The responses of the larvae of Mytilus edulis L. to light and to gravity. Oikos 15(1): 162-174

Bayne, B. L. (1965). Growth and delay of metamorphosis of the larvae of Mytilus edulis L. Ophelia 2:1-47

Bayne, B. L. (1976). Marine mussels: their ecology and physiology. Cambridge University Press, Cambridge, p. 81-120

Carriker, M. R. (1986). Influence of suspended particles on biology of oyster larvae in estuaries. Am. malac. Bull., spec. edn. 3: $41-49$

Chanley, P., Andrews, J. D. (1971). Aids for identification of bivalve larvae of Virginia. Malacologia 11(1):45-119

Cragg, S. M. (1980). Swimming behaviour of the larvae of Pecten maximus L. (Bivalvia). J. mar. biol. Ass. U.K. 60 : $551-564$

Demers, A., Lagadeuc, Y., Dodson, J., Lemieux, R. (1993). Immunofluorescence identification of early life history stages of scallops (Pectinidae). Mar. Ecol. Prog. Ser. 97: 83-89

Fortier, L., Leggett, W. C. (1982). Fickian transport and the dispersal of fish larvae in estuaries. Can. J. Fish. Aquat. Sci. 39: $1150-1163$

Frost, B. W. (1988). Variability and possible adaptative significance of diel vertical migration in Calanus pacificus, a planktonic marine copepod. Bull. mar. Sci. 43: 675-694

Gallager, S. M., Mann, R., Sasaki, G. C. (1986). Lipid as an index of growth and viability in three species of bivalve larvae. Aquaculture 56: 81-103

Gelder, S. R., Robinson, W. E. (1980). Identification of phaeopigments in the digestive gland of Mytilus edulis L. by microspectrofluorimetry. J exp mar. Biol. Ecol. 43: $281-292$

Harding, G. C., Vass, W. P., Hargrave, B. T. (1986). Diel vertical movements and feeding activity of zooplankton in St-Georges Bay, N.S., using net tows and a newly developed passive trap. Can. J. Fish. Aquat. Sci, 43: 952-967

Harvey, M., Bourget, E., Miron, G. (1993). Settlement of Iceland scallop Chlamys islandica spat in response to hydroids and filamentous red algae: field observations and laboratory experiments. Mar. Ecol. Prog. Ser. 99: 283-292

Hawkins, A. J. S., Bayne, B. L., Mantoura, R. F. C., Llewellyn, C. A. (1986). Chorophyll degradation and absorption throughout the digestive system of the blue mussel Mytilus edulis L. J. exp. mar. Biol. Ecol. 96: 213-223

Head, E. J. H. (1992). Gut pigment accumulation and destruction by arctic copepods in vitro and in situ. Mar. Biol. 112 $583-592$

Holm-Hansen, O., Lorenzen, C. J., Holmes, R. W., Strickland, J. D. H. (1965). Fluorometric determination of chlorophyll. J. Cons. 30: 3-15

Kaartvedt, S., Aksnes, D. L., Egge, J. K. (1987). Effect of light. on the vertical distribution of Pecten maximus larvae. Mar Ecol. Prog. Ser. 40: 195-197

Le Pennec, M. (1980). The larval and post larval hinge of some families of bivalve mollusca. J. mar biol. Ass. U.K. 60: $601-617$

This article was submitted to the editor
Lutz, R., Goodsell, J., Castagna, M., Chapman, S., Newell C., Hidu, H., Mann, R., Jablonsky, D., Kennedy, V., Siddal, S., Goldberg, R., Beattie, H., Falmagne, C., Chestnust, A., Partridge, A. (1982). Preliminary observations on the usefulness of hinge structures for identification of bivalve lar vae. J. Shellfish Res. 2(1): 65-70

Mackas, D., Bohrer, R. (1976). Fluorescence analysis of zooplankton gut contents and an investigation of diel feeding patterns. J. exp. mar. Biol. Ecol. 25: 77-85

Manahan, D. T., Crisp, D. J. (1983). Autoradiographic studies on the uptake of dissolved amino acids from sea water by bivalve larvae. J. mar. biol. Ass. U.K. 63: 673-682

Mann, R. (1977). An assessment of the use of pigment content as a feeding index in oysters. Aquaculture 10: 373-376

Mann, R. (1985). Seasonal changes in the depth-distribution of bivalve larvae on the southern New England shelf J. Shellfish Res. 5(2): 57-64

Mann, R. (1986). Sampling of bivalve larvae. Can. Spec. Pub] Fish. Aquat. Sci. 92: 107-116

Mann, R., Bernardita, M. C., Luckenbach, M. W. (1991). Swimming rate and responses of larvae of three mactrid bivalves to salinity discontinuities. Mar. Ecol. Prog. Ser 68: $257-269$

Martin, Y P., Mengus, B. M. (1979). Utilisation de souches bactériennes sélectionnées dans l'alimentation des larves de Mytilus galloprovincialis LMK (mollusque bivalve) en élevages expérimentaux. Aquaculture 10: 253-262

Pechenick, J. A., Eyster, L. S., Widdows, J., Bayne, B. L. \{1990). The influence of food concentration and temperature on growth and morphological differentiation of blue mussel Mytilus edulis L. larvae. J. exp. mar Biol. Ecol. 136: $47-64$

Prieur, D. (1983). Ingestion et digestion de bactéries par les larves de la moule Mytilus edulis L. J. molluse. Stud. Suppl. 12A: 149-153

Rothschild, B. J., Osborn, T. R. (1988). Small scale turbulence and plankton contact rates. J. Plankton Res. 10(3): $465-474$

Scrope-Howe, S., Jones, D. A. (1986). The vertical distribution of zooplankton in the Western Irish Sea. Estuar. coast. Shelf Sci. 22: 785-802

Strickland, J. D. H., Parsons, T.R. (1972). A practical handbook of seawater analysis, 2nd edn. Bull. Fish. Res. Bd Can. 167

Sullivan, C. M. (1948). Bivalve larvae of Malpeque Bay, P.E.I. Bull. Fish. Res. Bd Can. 77: 1-36

Tremblay, M. J., Meade, L. D. (1987). Identification of planktonic sea scallop larvae (Placopecten magellanicus) (Gmelin). Can. J. Fish. Aquat. Sci. 44: 1361-1366

Tremblay, M. J., Sinclair, M. (1990a). Sea scallop larvae Placopecten magellicanus on Georges Bank: vertical distribution in relation to water column stratification and food. Mar. Ecol. Prog. Ser. 61. 1-15

Tremblay, M. J., Sinclair, M. (1990b). Diel vertical migration of sea scallop larvae placopecten magellscanus in a shallow embayment. Mar. Ecol. Prog. Ser. 67: 19-25

Manuscript first received: June 15, 1993

Revised version accepted: October 11, 1993 